\title{
THE MEANING OF LIFE ON WARIA LIVING WITH HIV/AIDS (HUMAN IMMUNODEFICIENCY VIRUS/ACQUIRED IMMUNE DEFICIENCY): A PHENOMENOLOGICAL STUDY
}

\author{
Nur Amin Barokah Asfari \\ Ms., Universitas Gadjah Mada, Indonesia, nur.amin.b@mail.ugm.ac.id
}

\begin{abstract}
The existence of waria (a melding of two Indonesian words: wanita (woman) and pria (man) has not been recognized in some places, including in Indonesia. As the third-gender community, they often get discrimination from their surroundings. Therefore, they tend to limit their interaction with others, outside their community. Some of them work as sex workers. So, they are vulnerable to be infected with HIV/AIDS. Waria who is living with HIV/AIDS will feel meaningless at the first time. Sometimes, they choose to give up and end their life. However, some of them become HIV/AIDS survivors. Those who have a purpose in their life will be more motivated to continue their life better. This research is a qualitative study using phenomenological approach. This study aims to understand the process of finding the meaning of live on waria living with HIV/AIDS. A subject was involved in this study with characteristics: (1) were transsexual and (2) positively infected with HIV/AIDS. The participant will be interviewed about the participant's experiences to find the meaning of life. The results showed that the participant has meaningless phases when knowing that the participant had HIV/AIDS at first. The participant had time to give up. The participant felt the life the participant has would be ended soon. But, after contemplating, the participant thought that the participant had to use time to repent. The participant regretted all the mistakes in the past. The participant hoped that God would give His forgiveness. The participant wanted to be a better person, therefore, the participant began to act with better attitude. The participant is committed to the meaning of life and directed all activities to achieve it. The participant becomes more religious and has more pro-social behaviors. For ten years, the participant has worked as a volunteer for people with HIV/AIDS, especially for waria in Yogyakarta. The participant is satisfied with participant's life now as well feels more valuable because the participant can be a useful person to others.
\end{abstract}

Keywords: the meaning of life, waria, HIV/AIDS, phenomenological study

\section{INTRODUCTION}

Most people think that HIV/AIDS is a curse. People living with HIV and AIDS (then called PLWHA) is regarded as a despicable human sinner. Lack of knowledge about this disease causes the PLWHA to receive some discrimination, especially from their surroundings. Therefore, they often hide the truth about their real illness. Even, some of them refuse to go to the doctor because they do not want to be rejected. As a result, they cannot get the right treatment immediately. This condition causes the PLWHA to be more depressed. 
Besides, as a PLWHA, status of waria adds its own impact for them. The term waria is almost similar with the term transgender in abroad. Waria was born as a boy, but during their life journey, they experience some changes: they feel that they are actually women. More extremely, a waria even feels that her soul is trapped in man's body. Therefore, waria would feel more comfortable to dress up and behave like a woman. However, uniquely, they do not do genital surgery even though they feel themself as women. To most society, especially in Indonesia, the existence of waria has not yet been acceptable in society. Waria is regarded as a sinner because they deny their nature as a man. Thus, waria is often excommunicated from social relationship in society. Various negative stigma are also labelled to them, such as sinner, homosexual, free sex doer, and etc. These negative stigma make them expelled from their community. Due to this fact, waria would create their own community as a form of social support. Besides, they also find difficulties in finding jobs because most companies reject them. This condition forces them to work independently, for example by becoming a prostitute. Therefore, they are susceptible to be infected with HIV/AIDS.

Their physical condition that is weaken by HIV/AIDS, discrimination as well as rejection from society towards them make waria living with HIV/AIDS to be more stressful and tend to suffer from depression. Even worse, they might choose to give up with their conditions. For instance, they become indiscipline in taking medicine, which only weakens their self until they finally die.

An NGO in Yogyakarta, Indonesia, which focuses on waria and PLWHA mentioned that there is at least one waria living with HIV/AIDS in community dies every month due to their own behavior. Many stressors and pressures which they must face cause them to give up on their condition. Having no spirit of life and being hopeless make them reluctant to continue their life. Most of them assume that they have no more hope to live since AIDS is unable to be cured. Eventually, they begin to be indiscipline in taking their medicine because they think that it is useless since there is no medicine which can heal them. Or in other cases, they prefer death because they are unable to handle the pain they are living with, worsen by rejections from their surroundings.

But, some of them who have purpose in their life tend to have a motivation to get better. It can encourage them to try achieving what they desire. It can raise their spirit to continue their life. They will direct all their capacity to reach what they set as a goal. And this goal makes their life meaningful.

Research upon the meaning of life has been conducted by some researchers before. David Philip's study (in Alfian and Goddess, 2003) reveals that without the meaning of life there will be a void of the soul. This can lead to suicide cases in adolescents. Rohmah (2011) reveals that the elders who have the meaning of life will feel happier in living their life. Sumanto (2006) explains that the meaningfulness of life can encourage individuals to fight in their life.

This study aims to understand the meaning of live on waria living with HIV/AIDS focusing on the process of finding the meaning of life.

\section{LITERATURE REVIEW}

The concept of meaning of life is first proposed by Viktor Frankl. He is a Jewish who lived in the Nazi concentration camp. For three years, he observed the life of the prisoners there. He found that the meaning of life is very important to one's life (Bastaman, 2007). Meaning of life is defined as something essential for each person. Something is believed as true. People who turn the meaning of life as the life goal, will direct their life to achieve that goal.

Frankl (2006) stated that the meaning of life is an experience that is obtained by responding to the environment. It means that the meaning of one's life must be discovered by her/himself alone. He adds that in this process of searching, it can involve individual experiences related to God. The meaning of life can be manifested in a desire to be a useful person to others (Bastaman, 2007). People will find themselves useful and valuable when they can help others around them. Individuals who have meaningful life will tend to feel satisfied during their life. They will also be able to overcome problems that arise in their life better (Frankl in Koeswara, 1987).

Frankl (in Bastaman, 2007) mentioned that three components in meaning of life include: (1) freedom of will, (2) will to meaning, and (3) meaning of life. There are three ways to discover the meaning of life, they are: (1) obtaining through work, (2) experiencing something, and (3) responding to suffering (Frankl, 2006)

Bastaman (2007) also added that the components determining a person's success in making changes from living meaningless to meaningful life are self-insight, the meaning of life, changing attitude, self-commitment, directed activities, and social support. 
The process of finding the meaning of life include: the stages of suffering (tragic events, meaningless devaluation), self-understanding stage (self-understanding change of attitude), life-meaning stage (finding meaning and determination of purpose of life) the attachment of dying, directional activity, and the discovery of meaning to life), meaningful life stages (meaningful appreciation, happiness).

Human Immunodeficiency Virus (HIV) threatens human's health because it attacks the immune system. Whereas the immune system serves as a lifelong protection of the human body by recognizing, inhibiting, and attacking any incoming foreign body, so that the physical condition remains healthy (Mofenson, et.al,, 2009; Nursalam \& Kurniawati, 2007).

HIV is a viral agent with a nucleic acid (RNA) that belongs to the genus Lentivirus, Retrovirus class, Retroviridae family (Soedarto, 2009). The HIV RNA can form HIV DNA and replicate itself by using human immune system. This can lead to the gradual destruction of immune system, so the body is susceptible to opportunistic infection (OI) (Taylor, 2009). Infections from microbes that are usually non-pathogenic (virulent) or virulent (wherever is infectious), but under certain circumstances may be virulent if the host's immunological capacity is impaired.

Meanwhile AIDS is a collection of symptoms of disease or syndrome. It is occurred because the body has a decreased immune system (Mofenson et al., 2009). It is characterized by Ol with or without unusual neoplasms, such as Kaposi sarcoma that occurs in individuals less than 60 years old (Bellanti, 1993). Stewart (Nursalam \& Kurniawati, 2007) describes some of the psychological responses when a person is positively diagnosed with HIV/AIDS in the table 1.

Table 1. Psychological Response People with HIV/AIDS

\begin{tabular}{|l|l|l|}
\hline \multicolumn{1}{|c|}{ Reaction } & \multicolumn{1}{|c|}{ Psychological Response } & \multicolumn{1}{|c|}{ Things can be found } \\
\hline Shock & $\begin{array}{l}\text { Feeling guilty, angry, and } \\
\text { helpless. }\end{array}$ & $\begin{array}{l}\text { Fear, loss of mind, } \\
\text { frustration, sadness, trouble, } \\
\text { acting out. }\end{array}$ \\
\hline Withdrawal & $\begin{array}{l}\text { Feeling flawed, useless, and } \\
\text { self-isolating. }\end{array}$ & $\begin{array}{l}\text { Worried to infect others, } \\
\text { moody. }\end{array}$ \\
\hline $\begin{array}{l}\text { Restrict limited } \\
\text { status }\end{array}$ & $\begin{array}{l}\text { Wanting know the reaction of } \\
\text { others, stress diversion, and } \\
\text { wanting be loved. }\end{array}$ & $\begin{array}{l}\text { Rejection, stress, and } \\
\text { confrontation. }\end{array}$ \\
\hline $\begin{array}{l}\text { Looking for } \\
\text { others who are } \\
\text { HIV positive }\end{array}$ & $\begin{array}{l}\text { Sharing feelings, recognition, } \\
\text { trust, strengthening, and social } \\
\text { support. }\end{array}$ & $\begin{array}{l}\text { Dependence, intervention, } \\
\text { disbelief in the secret holder } \\
\text { himself. }\end{array}$ \\
\hline Custom status & $\begin{array}{l}\text { Change of alienation into special } \\
\text { benefits, their difference } \\
\text { becomes special, needed by } \\
\text { others. }\end{array}$ & $\begin{array}{l}\text { Dependence, our dichotomy } \\
\text { and them (everyone looks } \\
\text { HIV-infected and responded } \\
\text { that way), over identification. }\end{array}$ \\
\hline $\begin{array}{l}\text { Behavioral } \\
\text { attachment to } \\
\text { others }\end{array}$ & $\begin{array}{l}\text { Group commitment and unity, } \\
\text { giving and sharing, feeling as a } \\
\text { group. }\end{array}$ & $\begin{array}{l}\text { Excessive blackouts, } \\
\text { reactions, and } \\
\text { compensation. }\end{array}$ \\
\hline Acceptance & $\begin{array}{l}\text { Integration of HIV status with } \\
\text { self-identity and balance } \\
\text { between the interests of others } \\
\text { with yourself. }\end{array}$ & $\begin{array}{l}\text { Apathetic and difficult to } \\
\text { change }\end{array}$ \\
\hline
\end{tabular}

Adopted from "Asuhan Keperawatan pada Pasien Terinfeksi HIVIAIDS," by Stewart in Nursalam \& Kurniawati, 2007. Copyright 2007 by Salemba Medika.

Munjas, Oliver \& Luna (1998) added some of the psychosocial responses experienced by PLWHA including fear, anxiety, craving, loss, depression, mania, psychosis, and suicide. The. highlights is that the most frequent responses are anxiety, depression, and depression responses.

Waria living with HIV/AIDS who have a meaning in life, will strive to achieve the things they aspire to. This is what keeps their spirit in living life on fire. The discovery of this meaning of life starts from the process of 
contemplation by the individual. In their contemplation, they tend to rethink their life purpose and seek to gain that.

\section{METHOD}

A qualitative method using phenomenological approach is applied in this study to explore how waria living with HIV/AIDS find the meaning of life. Researcher intend to dig deeper information into the appreciation of individuals in the process of finding the meaning of life (Smith, Flowers, \& Larkin, 2010). Besides, the observed case is still stigmatized in society, theredore, qualitative method is regarded to be the most appropriate method to comprehend participant's subjective understanding towards participant's life experience.

\subsection{Participant}

A participant is involved in this study with characteristics of: (1) were waria and (2) positively infected with HIV/AIDS. The participant will be interviewed about the participant's experiences to find the meaning of life. Participant received informed consent from the researcher before the interview.

\subsection{Data Collection}

This research uses a qualitative study by using in-depth interview. Multiple data collection techniques are used in this study, such as interview, direct observation, and document study.

Interviews were conducted twice face to face. First, the researcher explained the purpose of the study and gave informed consent to the participants. She signed it after reviewed it. Meanwhile demographic data was collected using demographic questionnaire. Participant asked the researcher to write down the answer as participant says.

The first meeting will explore about the process of finding the meaning of participant's life. All questions were directed to explore the process of achieving it. The questions are as follows: (1) please share what you feel when you know that you are positively infected with HIV/AIDS, (2) please share with me about things which motivates you to change into a better person than you were, (3) what is the purpose of your life at that time.

At the second time, the question was more directed to explore the meaningful aspects of participant's life which aims to understand the components of meaning of life, such as freedom of will, will to meaning, and meaning of life.

\subsection{Data Analysis}

The interviews were held face to face and were recorded in audio. The recordings were transcribed by the researcher. Then, the researcher asked the participant to review the written transcript. After that, the researcher classified the results of interviews into several categories, namely (1) participant's identity, (2) early symptoms of HIVIAIDS, (3) the impact of HIVIAIDS on participant's life, (4) tragic experience, (5) selfinsight, (6) finding the meaning and purpose of life, (7) changing attitude, (8) self-commitment, (9) directed activities, (10) meaningful life, (11) freedom of will, (12) social support, and (13) happiness.

\section{RESULT}

\subsection{The Symptoms and Impacts of HIV/AIDS}

The participant, SF, 57 years old, was born in Cilacap. While doing the interview, SF requested the researcher to call her with mak or mbak (a Javanese call for a woman). SF is the last child from five siblings, and all of them are girls. SF is graduated from elementary school. Even though SF was born as a boy, SF feels more comfortable to dress up like a girl. SF then started to wear girl outfit since elementary school. While at school, SF wore male uniform, but after school, SF more frequently dressed up like a girl. SF borrowed the dress from SF's mother or siblings.

"I have dressed up like that since I was a kid. I wore short pant when I went to school, but when I arrived home I wore skirt. I wore my mother's dress, kebaya." (W.R.01.317-318)

In 1982, SF went to Bandung and worked as a prostitute. At that moment, SF has become a waria. SF dressed up like a woman and interested to man. While doing a sexual intercourse, SF never wore a protection due to the lack of education. SF did not even feel worried to satisfy 5-10 customers in a night without any protection. 
"Yes, at first was in 1982, I moved to Bandung, became a prostitute. There, we, the prostitute, never wear protection. We never know if there is any sexual disease. If there is a guest, we just enjoy it. There can be 10, 5 visitors every night. Using no protection." (W.R.01.20-23)

In 2006, SF was diagnosed to be infected with HIV. SF often suffered from prolonged diarrhea and anemia. This caused SF's condition to get weaker day by day. Almost for a year, SF suffered from the pain and felt very weak.

"Then I did VCT. Apparently the result is positive." (W.R.01.231-233)

"So it was until 2007 my condition kept dropping. I suffered from diarrhea again and again until the beginning of 2007." (W.R.01.30-32)

Nevertheless, SF admitted that SF kept working to survive. Even though SF has found out that SF has positively infected with HIV/AIDS, SF kept doing the sexual activity without wearing any protection. According to SF, at that moment the use of condom has not yet been familiar. Even SF had no idea what condom is as well what it is for. On the other side, SF also feels guilty for transmitting the virus to the customers. SF feels sorry to them because they have not yet known that SF suffers from HIV/AIDS. However, SF realized that few of SF's friends were also infected from HIVIAIDS and were still working as usual. This fact reduced SF's guilty feelings because it was not only SF, but others also involved in transmitting the virus.
"Yes. I was still working, forcing myself. The most important thing is I can survive and eat every
"Well no. We didn't have condom, nor did we have any idea about it. Hehehe.. That was because our unknowingness, thus it was not my fault, hehehe. But yes sometimes I feel guilty to those (W.R.01.231-233) whom I have infected with the virus. Not just from me, though. Many of my friends too."

At first, SF chose to hide the truth because at that time HIV/AIDS was suggested as a cursed diseases which was only suffered by the ones who committed sins. Moreover, SF's status as a waria caused SF to receive unpleasant treatment from society. Even when SF was hospitalized, SF felt discriminated by the medical personnel. SF only assumed that the doctors possibly still have not understood thoroughly about the spread of HIV/AIDS virus, therefore, they avoided direct interaction to HIV/AIDS patients because they were afraid to be infected.

"I was commanded to redo the test. At that time there was no any data yet in PKPI. I was suffering from diarrhea over and over, therefore, I was brought to Bethesda. A week there, my food was like separated from others. I entered as common patient. So I don't know how it was back then. In 2007, the doctors still did not understand about this disease. They are probably hesitant. They even never look after me. For a week in Bethesda, it was only the nurse. So I was staying in a room for 5. My bed was surrounded with plastic. You know, disposable plastic, must be thrown away after use." (W.R.01.40-50)

SF also hide the status PLWHA from SF's surroundings. Even though SF's environment could accept SF's condition as a waria, SF was still afraid that SF would be expelled from the environment if the society knew that SF suffers from HIV/AIDS. If a neighbor asked about the illness, SF would say that it was only fever or diarrhea. SF's family was also untold until this research is conducted.

"I'm afraid to talk about this disease. I'm afraid that they will be scared of me." (W.R.01.51)

"No. They don't know. They just know that I'm now healthy. They don't know the disease." (W.R.01.127)

HIV/AIDS affects SF's physical condition to be easily tired and it results SF's health condition to decrease. This condition limits SF's space, especially in working. SF used to sell nasi uduk (a name of Indonesian food which is made of rice mixed with coconut milk) at home. However, this activity really drains SF's energy. SF must prepare everything since at 3 o'clock in the morning. It causes SF to be exhausted and sick. Then SF decides to stop selling nasi uduk (a kind of Indonesia's traditional breakfast menu).

"Physically, yes, if I feel too exhausted I would not feel fit. Well we are already B20 (medical term for HIV/AIDS), we are not allowed to be too tired. If we are tired, we will be sick. I used to sell nasi uduk at home." (W.R.01.129-130) 
IJASOS- International E-Journal of Advances in Social Sciences, Vol. III, Issue 9, December 2017

SF is actually very interested in culinary, moreover, SF used to join a culinary course. But due to SF physical condition, SF must stop working. SF even refused an offer from SF's family to join in their restaurant. SF only said that because of age, SF gets tired too easily.

"Someone offer me to work at his restaurant. But working for others is very tiring. Physically my condition cannot stand it. My grandson in Kalimantan also wanted me to work in a restaurant. Mbah (grandma), come mbah, join me. I open a new restaurant. Help me cook. Mbah is tired, too old. Hehehe..." (W.R.01.307-310)

SF's physical condition affects the society's social response towards SD. At the beginning of the HIVIAIDS diagnosis and in shelter house, SF could only rest up and reduce all the physical activities. SF felt so much pain all over SF's body and weak. Because of that, other house occupants assumed that SF was just lazy and the pain SF felt was only due to lacking of exercise. This added another stressor for SF because SF thought that other people could not understand how SF feeling was since they did not stand on SF's feet. Others only saw her resting while in face SF rested up because SF felt weaker from time to time.

"For a week I felt weak, then I got weaker on week two, more and more until three weeks. Finally my friends complained me to do exercise not just sleeping. They just saw me sleeping everyday. Well they have no idea how I am feeling." (W.R.01.64-66)

\subsection{Tragic Event}

SF surprised at the first time SF found out that SF was infected with HIV/AIDS. At that time SF only thought about death. SF regards that HIV/AIDS is similar with death sentence because it cannot be healed, thus, the only thing which can be done is waiting for death to fetch up. Negative thoughts as such triggered anxiety which caused SF to experience insomnia for three nights. Nevertheless, SF was enlightened and supported by SF's friends that SF still can survive and not hopeless.

"Yeah. There is an NGO. I joined there. Then I did VCT. Turned out the result is positive. I was shocked. I was really shocked when I knew the result. Then I asked when I would die because people said that when someone suffers from HIV, it takes only a week or a month for them to live." (W.R.01.27-29)

"No. Never. I was just shocked at the beginning. Just shocked. Well it made me unable to sleep until three days in rows. Yeah I could not sleep, knowing that people living with HIV only need to wait for few weeks and months (to die). It was very shocking, you know. But yeah after my friends gave the solution I was not shocked anymore." (W.R.01.145-149)

Even though SF is fully supported by other waria friends, SF still needs to work to survive. Almost every night SF insists to work as a prostitute.

"Well that's it. I work every day, every night. Yeah I am still working, forcing myself. As long I can survive. I can eat every day." (W.R.01.227-229)

\subsection{Participant's Self-understanding towards Current Condition.}

SF obtained social support from other waria friends who suggested SF to consume carrot juice so that SF's physical condition remains strong. Though it did not taste good, SF took the juice every day because SF was certain that it is good to improve SF's physical condition. SF is also obliged to stay motivated in curing the disease and try the best to improve SF's health.

"They told me to drink carrot juice every day. But at that time it did not taste good at all. But I drank it anyway. Yeah that's it. We were at war to stay motivated. So I am not... to eat anything to heal myself. Never have I ever been lazy." (W.R.01.157-159)

\subsection{Finding the Meaning of Life.}

SF contemplates SF's life again and regrets SF's past attitude when SF worked as a prostitute. SF starts to get closer to God and hopes that He will forgive SF's sins before SF dies. SF uses the time to pray to atone the sins.

"Until now, all we can say is alhamdulilah that we can get closer to God. Ya Allah, hopefully God accepts it. Five times compulsary prayer. Well, even though it is not perfect but I do the prayers regulary to atone my sins. I surrender everything to Him, though. Wheter or not $\mathrm{He}$ is willing to accept it, the most important thing is my intention to pray, to worship Him. To reduce my sins. So yeah, up to now, I can say alhamdulillah." (W.R.01.99-103) 
IJASOS- International E-Journal of Advances in Social Sciences, Vol. III, Issue 9, December 2017

SF's desire to recover is triggered by SF's wish to meet SF's biological mother in Cilacap. SF admits that since SF has moved to Bandung, SF has never been gone back to Cilacap because SF has no money to afford the cost. The desire to return home motivates SF to survive and recover. SF wants to take care of SF's mother, the only parent who is still alive. SF hopes that SF still has a chance to do it. SF always prays that SF will not die before SF's mother. This desire is what keeps SF stay motivated. SF wants to live longer so that SF can return home and meet SF's mother and siblings.

"Yeah, I still have parents. I still have my mother. That's where my spirit comes from. I want to protect my parent. I wish I wouldn't die first, before my mother. So yeah, it keeps me motivated." (W.R.01.123-125)

"So we just say Bismillah. Ya Lord, give me health, long life. Blessed me with Your fortune, so that I can return to my hometown. I still want to meet my parent, my siblings. We always pray like that." (W.R.01.195-197)

"Yes I'm not giving up. I still want to survive. Ya Lord, give me long life. Give me health." (W.R.01.71-73)

On the other hand, SF also wants to live longer so that SF can repent the sins. SF admits that SF regrets everything SF did in the past. SF wish that God would give His forgiveness. SF becomes more religious after infected with HIV/AIDS. Besides doing usual prayers, SF also tries to help others. SF hopes that by helping others, God will note it as good deeds to atone the sins SF committed back then.

"Yeah that's it. Doing good deeds. Taking care of others, helping others. Worshipping God is not only by praying. Helping others, helping friends, are also the form of worship." (W.R.01.352-353)

SF devotes herself in NGO and works sincerely to help other waria who suffers from HIV/AIDS. SF feels to have more valuable life when SF can help others. SF feels that SF's life now is more meaningful since SF works in that NGO. SF recalls the memories at the beginning of SF's HIVIAIDS diagnosis and how SF can get up and move on now. SF feels that the support given by SF's friends has helped SF a lot to rise and survive. Therefore, SF feels grateful for the life SF living now and hope that other waria who suffers from similar condition can survive as well.

"Yes, we actually has had a thought to be useful for others. And Alhamdulillah, by our prayers, since we are here, for people and friends we are still useful. Still used by mommy NN. Well, we are very thankful, especially to God, for giving us long life, fortune, and also to mommy NN, for taking care of me, giving me shelter for these 10 years long. Also to my friends for supporting me, giving me positive motivations and suggestions." (W.R.01.286-291)

SF is then trusted to be the person in charge in the shelter house for waria and PLWHA, started from cleaning up the house, as well as taking care those who are sick. SF is delighted with the responsibility given to SF, including taking care of one of the occupant's baby.

"Well I am trusted to handle everything here. Cleaning the house, cooking, looking after those who are ill. Everything. Everything is trusted to me. Moreover, there is a baby here now. So I cannot go out freely." (W.R.01.348-350)

SF always tries to motivate other house occupants to be more motivated in continuing their life. SF also tries to be patience in facing various characters from them, even though sometimes SF needs to be assertive so that they can revive and face the truth sincerely.

"Yeah sometime I also think, I used to be like this. Back then, an occupant was being so problematic here. She does not want to take medicine, nor to eat. It makes me depressed to. It is so stressful to think of this and that, to overcome it, to motivate this person, so that she is willing to take her medicines, to eat. Sometimes I talk roughly. I used to suffer like you even worse, worse than yours. So please can you just obey me, listen to me. If I am stressed out, my condition will drop again. I don't want it. Now it is your choice, you have two. I even talked like that. You want to live or die? If you want to live, to be healthy, take your med, eat. If you want to die it is all up to you then. I talked like that. Well it is actually not good to talk that way. I am her partner but I talk that rough. But I was so annoyed. I want her to rise up. But sometimes some are motivated, some are not. But many has died. Yesterday, 4 people died here. LSL. Young. Good looking. They did not take their medicines regularly. Yes... I want to help friends who still need to be helped. They have already been like friends. But it is not because I am rich? I just want to help others." (W.R.01.368-398) 
IJASOS- International E-Journal of Advances in Social Sciences, Vol. III, Issue 9, December 2017

For her, the most important thing for her now is to worship and get closer to God. In addition to the form of prayer, SF considers helping others as well as worship.

\subsection{Change of Attitude}

SF profound desire to recover and survive influences SF's life style and attitude. SF, who wants to repent her sin, admits that SF does not want to work as a prostitute anymore. SF has ignored invitation from other house occupants as well as from other waria to work as a prostitute again.

"Yes, right. Now I never go out at night again. It's alright for me." (W.R.01.222-223)

"No. I never thought of becoming a prostitute ever again. Sometimes some friends still invite me. Nopi, Mbak Nopi, SF let's go out for Saturday night. No. I don't want to." (W.R.01.295-296)

Besides, SF is also discipline in taking medicines. According to SF, the most important thing as a patient of HIV/AIDS is taking the medicine regularly and thinking positively. Regularly taking medicine is an obligation for SF. Besides, SF should maintain a positive mindset. PLWHA must think positively because negative thoughts can cause stress which will only worsen PLWHA's health condition.

"Yes. It must be regular. Not skipping it. And not late either." (W.R.01.106)

"No. We don't have such thoughts. We must have positive thought, and stay motivated. So we are just chill. No need to dream too high. The most important thing is to be healthy. I never think of being a useless person. It's enough. I don't have such thought. No. We just think positively. No need to hope too much, dream too high, or anything negatives. It will just make me more stress. Even though people think I am a useless person. It's positive, eh, I mean negative thoughts. I have already suffered from HIVIAIDS. I don't need to think negative. Just focus on what's positive. I'm already suffered, I must change my way of thinking. Well, not just me, so do my friends. Many of them can survive. Perhaps, we just need to regularly take the medicines. Have enough rest and food. It's enough. Alhamdulillah." (W.R.01.111-120)

\section{DISCUSSION}

The participant experienced unpleasant period at the beginning of her HIV/AIDS diagnosis, because this disease does not only affect participant's condition physically, but also socially and psychologically. A weaken physical condition, guilty feeling (Kang, Rapkin, Remien, Mellins, \& Oh, 2005) as well negative response from society in participant's environment will worsen participant's psychological condition. Various negative stigma labelled to PLWHA can be stressors which trigger depression (Alexias, Savvakis, \& Stratopoulou, 2016; Boarts, Sledjeski, Bogart, \& Delahanty, 2006; Kalichman et al., 2009; Tao et al., 2017). It adds more stressor to participant and causes anxiety fear, if the participant's status as a HIVIAIDS patient is revealed. This fact is in line with the research, therefore, the participant tries to hide the true condition (Audet, McGowan, Wallston, \& Kipp, 2013; Judgeo \& Moalusi, 2014) and only open up about the actual condition for academic purpose.

The participant's anxiety is understandable. Society's lack of knowledge about HIV/AIDS, especially about the transmission of this disease to others scares them. They tend to avoid every kind of contact or communication to HIV/AIDS patients because they are afraid to be infected. As a result, many of HIV/AIDS patients receive discriminative treatment and negative label from the society. This condition will just worsen their health condition (Sarikusuma, Hasanah, \& Herani, 2012). Moreover, their status as waria evokes negative stigma to the society (Chidiac \& Connoly, 2016).

Even though the patient experiences meaningless phase at the beginning of their HIV/AIDS diagnosis, SF tries to revive and survive resulted from her friends support. Social support can help the participants in the process of finding the meaning of life (Astuti \& Budiyani, 2008). In addition, her desire to meet and take care of her biological mother motivates her to survive. This desire then becomes SF's life goal. This goal triggers her motivation to live a better life and direct the attitudes to achieve it. SF's desire to meet and take care of her mother is regarded as a form of regret upon SF's mistake in the past. SF hopes that by taking care of her, God will forgive her sins. Therefore, SF always tries to maintain her health by taking medicines, keeping healthy life style, and always thinking positively. This can bring up optimism in SF's self to have a better life (Audet, Wagner, \& Wallston, 2015).

SF's finding upon the meaning of life is begun from the contemplation process when SF rethinks of life SF has been living. SF feels sinful for disobeying God's command by committing adultery. SF is afraid of the punishment in hell. Therefore, SF's desire to repent and to seek for God's blessing appears and from that moment on SF starts to pray regularly in hope that God will forgive SF's sins before death fetches up. SF 
then becomes more motivated to continue SF's life because SF still wants to worship God more in order to seek for His forgiveness.

SF's desire to survive is also motivated by the desire to meet and take care of SF's biological mother in SF's hometown. SF feels that by being devoted to SF's parent can also reduce the sins. Besides, SF feels more valuable and useful if SF can take care of her.

SF's method of worshipping God is not only shown up by doing compulsary prayers, but also by doing good deeds to other people. Since living in a shelter house, SF devoted herself to help her PLWHA friends. SF is the one who takes care of all their needs. SF does this solely because she wants to help others. She hopes that what she does is recorded as a form of worship.

SF always remembers her own story. She realizes that she can achieve her condition at this time due to the support she received from her friends. Life in shelter homes that are like family helps SF to perform the social function (Siboro, 2014). SF sees her previous condition back then, when she was suffered, as a motivation to survive. SF hopes that others can imitate herself and even live better than her. SF always motivates other PLWHA to stay focus on their health by taking the medicines, keeping healthy life style, and always thinking positively. SF hopes that in the rest of her life, she can worship and get closer to God. SF regretted her actions in the past. She hopes her actions to help others can reduce her sins.

For SF, her life will be meaningful if she can be useful to others. The meaning of life affects SF's attitude (Fife, 2005). SF helps other people living with HIV so that they can accept the conditions. Because, if people living with HIV / AIDS reject the condition, it will make them more depressed (Nam et al., 2008). Therefore, SF keeps herself healthy so she can be an example as a successful PLWHA (survivor).

Besides, helping others can lead to happiness in SF. SF is happy because she still has the ability to help others. By helping them, SF can provide social support to others, as well as get social support from the people she helps. This reciprocal relationship is due to the feeling of being the same as PLWHA. SF also assumes that helping others can make her closer to God. This is in line with the findings of Arriza, Dewi, \& Kaloeti, (2011) that social support and religiosity can lead to happiness in people living with HIV. Social support can also improve the quality of life of SF as an ODHA (Burgoyne \& Renwick, 2004).

\section{CONCLUSION}

Based on the description, it can be concluded that: meaningless phase can be found when the participant knows that she is infected with HIV/AIDS for the first time. However, participant's life goal has motivated the participant to fight and live a better life. Social support can help the participant in the process of achieving the goal. A better motivation which she has is visible through her discipline attitude in taking medicines and always thinking positive. Participant feels that her life is more meaningful and more valuable if she can help others, because helping others is regarded as a form of worshipping God, which later supports her life goal to get closer to Him.

\section{ACKNOWLEDGEMENT}

I would like to thank Lembaga Pengelola Dana Pendidikan (LPDP - Indonesian Fellowship) for supporting my study in Master of Psychology.

\section{REFERENCE LIST}

Alexias, G., Savvakis, M., \& Stratopoulou, I. (2016). Embodiment and biographical disruption in people living with HIV/AIDS (PLWHA). AIDS Care, 28(5), 585-590. https://doi.org/10.1080/09540121.2015.1119782

Alfian, I.N \& Dewi, R.S. (2003). Perbedaan tingkat kebermaknaan hidup remaja akhir pada berbagai status identitas ego dengan jenis kelamin sebgai kovariabel (Penelitian terhadap mahasiswa Madura di Surabaya). Insan Media Psikologi Vol. 5, no,2:87-89

Arriza, B. K., Dewi, E. K., \& Kaloeti, D. V. S. (2011). Memahami rekonstruksi kebahagiaan pada orang dengan HIV/AIDS (ODHA). Jurnal Psikologi Undip, 10(2), 153-162.

Astuti, A., \& Budiyani, K. (2008). Hubungan antara dukungan sosial yang diterima dengan kebermaknaan hidup pada ODHA (orang dengan HIV/AIDS). Yogyakarta: Fakultas Psikologi Universitas Mercu Buana. Retrieved from http://fpsi.mercubuana-yogya.ac.id/wpcontent/uploads/2012/06/Agustus_2010_Kondang-Budiyani.pdf 
IJASOS- International E-Journal of Advances in Social Sciences, Vol. III, Issue 9, December 2017

Audet, C. M., McGowan, C. C., Wallston, K. A., \& Kipp, A. M. (2013). Relationship between HIV Stigma and Self-Isolation among People Living with HIV in Tennessee. PLoS ONE, 8(8), e69564. https://doi.org/10.1371/journal.pone.0069564

Audet, C. M., Wagner, L. J., \& Wallston, K. A. (2015). Finding meaning in life while living with HIV: validation of a novel HIV meaningfulness scale among HIV-infected participants living in Tennessee. BMC Psychology, 3(1). https://doi.org/10.1186/s40359-015-0070-7

Bastaman, H.D. (2007). Logoterapi: psikologi untuk menemukan makna hidup dan hidup bermakna. Jakarta: Raja Grafindo Persada

Bellanti, J. A. (1993). Imunologi III, edisi bahasa Indonesia. Yogyakarta: Gadjah Mada University Press.

Boarts, J. M., Sledjeski, E. M., Bogart, L. M., \& Delahanty, D. L. (2006). The Differential Impact of PTSD and Depression on HIV Disease Markers and Adherence to HAART in People Living with HIV. AIDS and Behavior, 10(3), 253-261. https://doi.org/10.1007/s10461-006-9069-7

Burgoyne, R., \& Renwick, R. (2004). Social support and quality of life over time among adults living with HIV in the HAART era. Social Science \& Medicine, 58(7), 1353-1366. https://doi.org/10.1016/S02779536(03)00314-9

Fife, B. L. (2005). The role of constructed meaning in adaptation to the onset of life-threatening illness. Social Science \& Medicine, 61(10), 2132-2143. https://doi.org/10.1016/j.socscimed.2005.04.026

Frankl, V.E. (2006). Logoterapi: Terapi Psikologi Melalui Pemaknaan Eksistensi. Yogyakarta: Kreasi Wacana Yogyakarta

Judgeo, N., \& Moalusi, K. P. (2014). My secret: The social meaning of HIV/AIDS stigma. SAHARA-J: Journal of Social Aspects of HIV/AIDS, 11(1), 76-83. https://doi.org/10.1080/17290376.2014.932302

Kalichman, S. C., Simbayi, L. C., Cloete, A., Mthembu, P. P., Mkhonta, R. N., \& Ginindza, T. (2009). Measuring AIDS stigmas in people living with HIV/AIDS: the Internalized AIDS-Related Stigma Scale. AIDS Care, 21(1), 87-93. https://doi.org/10.1080/09540120802032627

Koeswara. 2987. Psikologi Eksistensial: Suatu Pengantar. Bandung. PT. Eresco

Mofenson, L. M., Brady, M. T., Danner, S. P., Dominguez, K. L., Hazra, R., Handelsman, E., ... Serchuck, L. (2009). Guidelines for the prevention and treatment of opportunistic infections among HIV-exposed and HIV-infected children: recommendations from CDC, the National Institutes of Health, the HIV Medicine Association of the Infectious Diseases Society of America, the Pediatric Infectious Diseases Society, and the American Academy of Pediatrics. MMWR. Recommendations and Reports: Morbidity and Mortality Weekly Report. Recommendations and reports/Centers for Disease Control, 58(RR-11), 1.

Munjas, B., Oliver, C. A., \& Luna, B. J. (1998). Psychosocial Responses. Dalam M. Ropka \& A. Williams (Eds.), HIV nurshing and symptom management. Jones \& Bartlett Publisher.

Nam, S. L., Fielding, K., Avalos, A., Dickinson, D., Gaolathe, T., \& Geissler, P. W. (2008). The relationship of acceptance or denial of HIV-status to antiretroviral adherence among adult HIV patients in urban Botswana. Social Science \& Medicine, 67(2), 301-310. https://doi.org/10.1016/j.socscimed.2008.03.042

Nursalam., \& Kurniawati, N. D. (2007). Asuhan keperawatan pada pasien terinfeksi HIV/AIDS. Jakarta: Salemba Medika.

Rohmah, Nur. (2011). Studi Deskriptif tentang Tingkat Kebermaknaan Hidup Lansia yang Tinggal di Unit Rehabilitasi Sosial Wening Wardoyo Ungaran. Skripsi. Universitas Negeri Semarang

Sarikusuma, H., Hasanah, N., \& Herani, I. (2012). Konsep Diri orang dengan HIV dan AIDS (ODHA) yang menerima label negatif dan diskriminasi dari lingkungan sosial. Psikologia: Jurnal Pemikiran Dan Penelitian Psikologi, 7(1). Retrieved from https://jurnal.usu.ac.id/index.php/psikologia/article/view/400

Siboro, H. K. (2014). Pengaruh dukungan keluarga terhadap keberfungsian sosial orang dengan HIV/AIDS (ODHA) di Rumah Singgah Caritas PSE Medan. Welfare StatE, 2(4). Retrieved from http://202.0.107.5/index.php/ws/article/view/6226

Smith, J.A., Flowers, P., Larkin, M., 2010

Soedarto. (2009). Penyakit menular di Indonesia. Jakarta: Anggota Ikapi. 
Sumanto. (2006). Kajian Psikologis Kebermaknaan Hidup. Buletin Psikologi, Vol 12 no 2

Tao, J., Wang, L., Kipp, A. M., Qian, H.-Z., Yin, L., Ruan, Y., ... Vermund, S. H. (2017). Relationship of Stigma and Depression Among Newly HIV-Diagnosed Chinese Men Who Have Sex with Men. AIDS and Behavior, 21(1), 292-299. https://doi.org/10.1007/s10461-016-1477-8

Taylor, S. E. (2009). Health psychology. US: McGraw-Hill Companies.

Utama, T. T \& Sanpedro, Y. (10 April 2015). Victory Plus: Pembawa Harapan bagi ODHA [web log post]. Diperoleh dari http://citralekha.com/victoryplus/ 